\title{
THE IMPACT OF WAGE \\ SUBSIDIES ON JOBSEEKERS' \\ OUTCOMES AND FIRM EMPLOYMENT
}

\author{
Sarah Crichton \\ Ministry of Business, Innovation and \\ Employment \\ Dave C Maré \\ Motu Economic and Public Policy Research
}

\begin{abstract}
Wage subsidies are commonly used to assist disadvantaged jobseekers into employment. If effective they can contribute to reducing long-term benefit dependence. The study examines the impact of wage subsidies on assisted jobseekers and on the firms that employ them. It focuses on hiring subsidies granted over the period of January 2003 to December 2007 and outcomes up to December 2010, and draws on administrative and tax data held by Statistics New Zealand as part of the 'Integrated Data Infrastructure' prototype. Outcomes for assisted jobseekers are compared to those of comparable jobseekers using propensity matching methods. Similarly, propensity-matching is used to compare employment and earnings growth in firms that hire subsidised workers to growth in otherwise comparable firms. Overall we find that starting a subsidised job leads to significant employment and earning benefits for assisted jobseekers over several years. Subsidised workers are disproportionately hired into expanding firms, though we cannot determine whether the expansion would have occurred in the absence of the subsidy.
\end{abstract}

\section{Introduction}

This study examines the impact of wage subsidies on assisted jobseekers and on the firms that employ them. It focuses on hiring subsidies granted over the period of January 2003 to December 2007 and outcomes up to December 2010.

Previous studies in New Zealand have found that wage subsidies are effective in moving jobseekers out of unemployment (Maré 2002) or off benefit (Johri et al. 2004; de Boer 2003). Survey evidence (Department of Labour 1985; New Zealand Employment Service 1994) suggests that wage subsidies improve the subsequent employment prospects of assisted jobseekers

The key original contributions of the current study are twofold. First, it extends previous New Zealand studies of the impact of subsidies on jobseeker outcomes by examining the impacts on subsequent employment and earnings, in addition to the impacts on subsequent benefit receipt and unemployment. Second, it presents evidence on the impacts of wage subsidies on employment in the firms that hire subsidised workers. It thus provides evidence on whether the gains for assisted jobseekers are achieved by placing them in previously filled jobs or in new jobs.
Our study makes use of data from Statistics New Zealand's Integrated Data Infrastructure (IDI), prototype which contains relevant administrative and survey information for a broad set of New Zealand workers and firms. This enables us to estimate the impacts of wage subsidies by comparing outcomes for assisted workers and firms with those of comparison groups with similar characteristics. Comparison groups are defined using the method of propensity score matching.

\section{Background}

Most wage subsidy evaluations focus on the impact of the subsidy on the prospects of the subsidised worker. This focus is appropriate given that the primary aim of wage subsidy policies is generally to help unemployed jobseekers into work.

These gains may, however, come at the cost of other workers or jobseekers. Effective design and delivery of wage subsidy programmes seeks to limit the costs of subsidies, which take the form of direct deadweight costs and indirect costs in the form of substitution or displacement effects. Deadweight costs arise when a subsidy is paid to a jobseeker who would have gained employment anyway, or who would have gained employment with a lesser subsidy. Managing eligibility 
for subsidies and negotiating the subsidy amount and duration can lower the risk of deadweight costs.

Substitution effects arise when the subsidised jobseeker fills a job that would otherwise have been filled by an unsubsidised worker. Unless subsidies can induce firms to increase employment, a degree of substitution is an unavoidable cost of achieving gains for subsidised jobseekers.

It is possible that a wage subsidy programme can induce firms to expand their employment, if for example the subsidy amount more than compensates the employer for the lower productivity of the subsidised worker at the time of hiring, and they may be willing to retain the formerly subsidised worker because doing so does not entail any hiring costs, and because the worker may have acquired relevant skills while subsidised.

A subsidy may make the employer willing to hire, or to bring forward a possible future hiring, ${ }^{1}$ by covering hiring and training costs, or by compensating them for taking the risk of hiring when there is uncertainty about future demand or about the productivity of a particular applicant.

There are relatively few studies that, like ours, examine the impact of subsidies on firm employment using a rich microdata panel. A number of earlier studies relied on surveys of firms to ascertain the extent of substitution or deadweight effects (for example, Department of Labour 1985; see also the summaries in Calmfors et al. 2001 and OECD 1993). These survey-based studies generally found substantial deadweight effects (60 percent of subsidised workers would have been employed anyway) and substitution effects (of the remaining 40 percent, 25/40 gain employment at the expense of other workers). The net expansion of employment is thus only about 5 to 10 percent of the number of subsidised workers (Maré 2005).

In contrast, more recent matching estimates using firm microdata find more substantial positive effects of subsidised employment on total employment at the firm. Using a similar matching approach to ours, and administrative data on firm employment in Denmark, Rotger and Arendt (2010) estimate the impact on employment 7 months after the start of a subsidy, when most subsidies are ended. Firms that had hired a subsidised worker have 0.26 more employees than in otherwise comparable firms. A related Finnish paper by Kangasharju (2007), reports that firms that took on subsidised workers increased their payroll by around 9 percent relative to a matched comparison group. The author interprets this as evidence that subsidies lead to increases in total employment. The results are, however,

\footnotetext{
${ }^{1}$ Department of Labour (1985) reported that $65 \%$ of subsidised placements arose from employers bringing forward future hiring. At the time, this was seen as evidence of strong deadweight costs — with the subsidy paying employers to do what they would have done anyway, which was influential in reducing the use of wage subsidies in the late 1980s.
}

also consistent with the take-up of subsidies being concentrated in expanding firms.

\section{Wage subsidy programmes}

There were a numbers of different subsidy programmes operating over the January 2003 to December 2007 period that we examine. About 12,500 subsidies were paid in 2003, decreasing to about 6,200 in 2007. The main programme over this period was called Job Plus which was a hiring subsidy paid to assist disadvantaged jobseekers to secure permanent employment, and accounted for 37,400 of the 46,500 subsidies paid over the period. Job Plus Training $(3,400)$ enabled clients to undertake specific training required for an identified job opportunity. Job Connection $(1,600)$ is a work experience subsidy $^{2}$ targeted to those who have been unemployed for more than 4 years. In 2007 Job Plus, Job Plus Training, and Job Connection were consolidated into a single programme called Skills Investment Subsidy.

The Job Plus wage subsidy programme was administered by the New Zealand Employment Service, and then by Work \& Income, between 1993 and 2007. It was a targeted subsidy programme aimed at disadvantaged jobseekers. The main, but not only, criterion for disadvantage was having been registered as unemployed for at least 6 months. The duration and amount of the subsidy was negotiated by the case manager and the employer. In most cases the duration of subsidy was for 26 weeks, although it could be up to 52 weeks.

Job Plus subsidies were paid to employers who employed particular jobseekers in permanent, full-time jobs. A pro rata subsidy could be paid for work-tested beneficiaries working 15-30 hours per week.

In 1999 , the subsidy amount was capped at $\$ 11,000$ per participant per year, which equates to \$214 per person per week for up to 52 weeks. Over the 2003 to 2007 the average subsidy was about $\$ 200$ to $\$ 250$ per week, while the median gross earnings while employed for subsidised workers in the 2 years prior to subsidy receipt was around \$430 per week, in June 2005 dollars. Subsidies were paid for about 50,000 jobs over this period, at an average cost of $\$ 3,000$.

Jobseekers could secure subsidised jobs in a number of ways. In some cases, employment advisors or case managers would negotiate with an employer prior to a jobseeker being referred to a posted vacancy. Employment advisors could also negotiate with employers who had not posted a vacancy, to encourage them to hire a subsidised jobseeker. Jobseekers could also apply for vacancies and inform prospective employers that employing the jobseeker would attract a subsidy payment. The operational principles guiding the delivery

\footnotetext{
${ }^{2}$ Work experience subsidies differ from hiring subsidies (like Job Plus) in that the employer is under no obligation to continue to employ the participant at the end of the subsidy period.
} 
of the programme required that the subsidy only compensate the employer for the extra costs of employment incurred by employing a disadvantaged jobseeker; that subsidised jobseekers should not replace existing employees; and that subsidies should not provide employers with a competitive advantage. Overall, the design and implementation of the programme favoured placing subsidised jobseekers into existing vacancies.

An evaluation of Job Plus was undertaken in 1994 (New Zealand Employment Service 1994). A sample of 400 subsidy recipients was interviewed 6 months after their subsidy ended. Information was collected on the length of their subsidy and on their employment experiences during and after the period of the subsidy. Almost half (44 percent) of subsidy recipients reported receiving a subsidy for fewer than 6 months. Six months after the subsidy ended, 39 percent of recipients reported that they were still employed at the firm in which they had received subsidised employment.

The current paper provides the first examination of the impact of Job Plus on the firms that hired the subsidised workers.

\section{Data}

We use data from the Statistics New Zealand prototype IDI dataset. This dataset contains information on benefit dynamics and active labour market policies, linked employer-employee data (LEED) on monthly employment and earnings derived from tax data, and information on firms' industry and location from the Statistics New Zealand Longitudinal Business Frame.

Monthly employment and earnings data are available from April 1999 until December 2010. We focus on subsidy spells that started between January 2003 and December 2007, to ensure that we have 3 years of prior and subsequent job information, covering January 2000 to December 2010. We also report longer-term outcomes for jobseekers who receive early in our study period.

The dataset includes main benefit payments (which are taxable) but not second or third tier benefit payments (like the accommodation supplement and hardship grants) Hence it is not possible to determine the total amount of benefits an individual received in any month.

For each person who receives a wage subsidy, the dataset contains information on the start date and the estimated duration over which the subsidy was paid. Information on the amount of subsidy paid or the identity of the employer is not included. The information on start date is considered to be more reliable than end date. We use administrative data on programme participation to identify all those who started a subsidised job between January 2003 and December 2007. This was about 60,000 people, most of whom received one subsidy over the 5year period. We treat subsidy spells separated by less than 30 days as a single spell which reduces the number of spells from 66,595 to 59,985 .
We use the linked data to identify those jobseekers who start a new job-spell around the time recorded in the administrative data. We match each subsidy start to the closest job-spell start within a given window. A match is made if the job-spell started in the same calendar month, up to 3 months before, or 1 month after the administrative start date. We don't include matches where the job-spell starts 2 or 3 months after that recorded in the administrative data because of the possibility that the jobseeker starts an unsubsidised job rather than a subsidised one at that time, whereas it seems unlikely that a jobseeker would receive a wage subsidy if they already have a job. In total, 46,469 subsidy spell starts are matched to a job start. It seems that a significant minority of jobseekers do not start the subsidised job as arranged.

The main study population is further restricted to those who had received benefits at some stage during the 12 months before the reference subsidy spell, and had not received a wage subsidy in the prior 6 months.

For the firm-based analysis, the unit of analysis is an enterprise, which may operate in more than one location. We apply some repairs to enterprise records, joining continuing enterprises that appear to have ceased, using the algorithm in Fabling (2011). We use financial information about firms from the Longitudinal Business Database, drawing on information from survey and administrative sources. From the available financial information, we are able to derive a measure of productivity for about a third of enterprises.

\section{Impacts of jobseekers}

\section{Method}

The impact of starting a subsidised job on subsequent outcomes is estimated using the method of propensity matching. Jobseekers are matched to similar jobseekers who did not start a subsidised job, on the basis of the estimated probability of starting a subsidised job. Differences in subsequent benefit, employment, and earnings of the treated and matched jobseekers indicate the impact of starting a subsidised job on subsequent employment and earnings. The method is implemented in three stages.

First, a pool of potential matches is identified for each calendar month, referred to as the reference month. We classify all jobseekers who start a subsidised job in the month as part of the 'treatment group'. A 'potential comparison group' contains all other jobseekers.

Table $1^{3}$ compares the demographic characteristics, and employment and benefit history of the 39,885 participants in our study population with a 1 percent random sample of non-participants in each calendar month. About twothirds of participants were receiving the Unemployment Benefit before they started the subsidised job, with one-

3 Tables and Figures are included in attached appendices 
third receiving other benefits. About 20 percent had been receiving benefit for less than 3 months when they started the subsidised job and 33 percent had been receiving benefit for 6 or more of the previous 10 years. Participants are more likely than non-participants to be on the unemployment benefit, male, young, Māori, and to have no school qualifications. They also have lower average duration on-benefit than the non-participants.

Second, we estimate a logistic regression model to obtain a predicted probability for each jobseeker of starting a subsidised job. The probability of treatment is modelled as a function of past benefit history, employment patterns, and demographic and other characteristics recorded in the administrative data. A separate logistic regression model is estimated for each type of main benefit, pooled across years. For those receiving the Unemployment Benefit, separate regressions are estimated by year. The regression models are estimated on a sample comprising all members of the treatment group, and a 10 percent sample of other jobseekers. Predicted probabilities are derived for all members of the treatment and comparison groups, and are referred to as 'propensity scores', following the terminology of Rosenbaum and Rubin (1983).

The third stage of the method is to match each treated jobseeker to a subset of similar comparison jobseekers. Matches are made only between jobseekers observed in the same reference month, and of the same sex, ethnicity, age class, and benefit type and duration class, to facilitate subsequent subgroup comparisons. Within those constraints, each treated jobseeker is matched to five comparison group jobseekers with the closest values of the propensity score. Those comparisons that are matched at least once are referred to as the 'matched comparison group'.

We drop individuals who have no comparators or those with propensity scores outside the region of common support. These restrictions reduce the number of subsidy starts from 39,885 to 38,808 , a match rate of 97.3 percent. The total number of jobseekers in the matched comparison group is 182,223 . This three-stage matching method serves to balance the average characteristics of the treatment and matched groups.

\section{Results}

Figure 1 plots various measures for participants and matched comparisons in the 36 months before and 36 months after the reference month (that is, the month participants started a subsidised job). We consider the proportion receiving benefits or subsidies (panel a), the proportion employed and off-benefit (panel b), the proportion employed, including both subsidised and unsubsidised employment (panel $d$ ), the proportion neither employed nor in receipt of benefits (panel e) and the proportion receiving a wage subsidy (f).

The wage subsidy usually lasts up to 7 calendar months, with only 5 percent receiving a longer subsidy. Differences in outcomes between participants and comparisons were greatest around 7 months, with participants much less likely to be receiving benefits, and more likely to be in unsubsidised employment.

Subsidised jobs usually last longer than the subsidy. About 58 percent of subsidised jobs continue after the subsidy ends, with 28 percent lasting at least 6 more. Jobs are more likely to continue after a longer subsidy spell. Following a 6-month subsidy, 56 percent of jobs last a further 6 months.

Twelve months after starting a subsidised job, 34 percent of participants are receiving benefits or wage subsidy, compared to 58 percent of matched comparisons (panel a). Fifty-two percent of participants are off-benefit and in unsubsidised employment, compared to 26 percent of matched comparisons.

Although differences between participants and comparisons decline gradually from around 7 months, large differences remain 36 months after starting a subsidised job. Thirty-six percent of participants receive benefits or a wage subsidy, compared to 45 percent of matched comparisons. Forty-five percent of participants are off-benefit and in unsubsidised employment, compared to 32 percent of matched comparisons.

Overall, participants are 13.0 percent more likely to be employed 36 months later, 10.2 percent less likely to be receiving benefit, and spend 6.1 more months employed, 5.0 fewer months receiving benefit, and earn \$20,150 more over the following three years than matched comparisons.

Table 2 also contains estimated impacts on various outcomes measures, for different demographic subgroups. Overall, positive impacts are evident for all subgroups defined by previous benefit receipt or by demographic characteristics such as age, gender and ethnicity.

\section{Impacts on firms}

\section{Method}

As for the analysis of jobseeker outcomes, the impact on a firm of hiring a subsidised worker is estimated using the method of propensity matching. Firms employing a subsidised worker are matched to a subset of similar firms, where similarity is defined on the basis of the estimated likelihood of taking on a subsidised worker. Differences in subsequent employment growth of the treated and matched firms indicate the impact of hiring a subsidised worker. The method is implemented in three stages.

First, a pool of potential matches is identified for each calendar month, referred to as the reference month.

Second, we estimate a logistic regression model to obtain a predicted probability for each firm of hiring a subsidised worker. The probability of treatment is 
modelled as a function of past employment patterns, recent workforce composition, industry, and region. A separate logistic regression model is estimated for each calendar year, and within year, by firm size ${ }^{4}$. The regression models are estimated on a sample comprising all members of the treatment group, and a 40 percent sample of other firms. Predicted probabilities are derived for all members of the treatment and comparison groups.

The third stage of the method is to match each treated firm to a subset of similar comparison firms. Matches are made only between firms observed in the same reference month and of the same size class. Within those constraints, each treated firm is matched to five comparison group firms with the closest values of the propensity score.

This three-stage matching method serves to balance the average characteristics of the treatment and matched comparison groups.

We focus attention on firms that hire one or more subsidised workers between January 2003 and December 2007. We restrict attention to subsidy starts in firms that have been employing continually for 3 months prior to taking on a subsidised worker. This excludes around 15 percent of subsidy starts during the period.

Our main impact estimates are based on for firms with average employment of 50 or less in the year prior to the reference month. We exclude larger firms, as it is more difficult to separate the relatively small influence of hiring a subsidised worker from general employment variation across time and across firms.

We observe 27,780 monthly observations on enterprises ('enterprise-months') for months in which one or more subsidised workers start an employment spell. Overall, 30,363 employees within these firms started a subsidised job during the period. There are $7,974,600$ potential comparison observations. The firms that take on subsidised workers have different characteristics from those that do not. Some key differences are summarised in Table 3. Treated firms are larger than the average comparison firm. They have average employment of 11.3 workers, compared with 6.1 for the potential comparison group. They also have higher employment growth, higher turnover, and are slightly younger. A higher share of their workforce is young or male, or has monthly earnings below the lower quartile. There are also differences in the geographic location and industry composition of treated and comparison firms. Subsidies are disproportionately high in construction services, food and beverage services, and food product manufacturing, and low, in agriculture

4 We undertook a supplementary analysis in which we control for firms' production histories. Treated firms not only have higher employment, but also have larger capital and intermediate inputs, compared with potential comparison firms, but were slightly less productive than comparison firms. Taking these differences into account improves the credibility of our impact estimates, although in practice these were very similar to our main estimates. and in the professional, scientific, and technical services industries.

In the matching stage, we drop firms for which we have no suitable comparators. This reduces the number of treated firms to 27,597 and the number of subsidy starts to 30,123 .

\section{Results}

In our analysis sample of treated and potential comparison group firms, the total number of subsidised jobs in any month declined from around 4,000 in 2003/04 to around 2,500 in 2007. Around one-third of subsidies were in firms that were hiring a new subsidised worker in the month.

Most firms hire only one new subsidised worker at a time, and employ only a few subsidised workers during the 2003-2007 period. In a month where a subsidy starts, firms on average take on 1.2 subsidised workers. However, 90 percent of firms take on only one subsidised worker at a time. The average is higher due to a relatively small number of (mainly larger) firms taking on multiple subsidised workers. About 65 percent firms who hire a new subsidised worker between 2003 and 2007 only ever take on one subsidised worker, with a further 17 percent only ever taking on two workers, which is close to the average of 2.1 workers.

We focus on employment outcomes for the firm. The main measure that we use is a count of total employment within a firm in each of the 36 months following the start of a subsidy spell. We also track the number of subsidised jobs in the firm, and the retention of previously subsidised workers.

Figure 2 provides a graphical summary of how the impacts are identified and estimated. The upper panel of Figure 2 plots mean employment for the treatment and comparison groups. The potential comparison group (dashed line) has slower growth than the treatment group in the 36 months prior to the reference month, and lower mean employment in the reference month. Identification relies on matching treatment and comparison firms that on average have similar employment growth and firm birth and death patterns. The figure shows clearly that the prior employment growth for the matched comparison group closely matches that of the treatment group. The two lines are indistinguishable on the graph. After the reference month, however, the mean employment levels of the two groups diverge markedly. The difference in employment levels between the treatment group and the matched comparison group is the estimate of the impact of subsidised hiring (effect of treatment on the treated).

The middle panel of Figure 2 plots the vertical distance between the bold 'treatment group' line in the upper panel and the corresponding 'matched comparison group' line. This is the 'average effect of treatment on the treated' (ATT), and is shown in the figure as a solid bold line. Prior to the reference month, the effect is close to zero. In 
the reference month, the effect rises sharply to 1.39 additional employees. The dotted lines in the middle panel show 95 percent confidence intervals for the average effect of treatment on the treated. ${ }^{5}$ The difference is significantly different from zero throughout the followup period of 36 months.

The lower panel of Figure 2 plots the same ATT line for total employment, together with lines showing the difference between the treatment and matched comparison firms in the number of subsidised workers and formerly subsidised workers employed in the firm each month. The immediate employment impact (month 0 ) is larger than the average number of subsidy starts in that month, which is 1.09 for firms with mean employment of 50 or less. The faster growth in employment among treated firms relative to the matched comparison group is not due entirely to the hiring of subsidised workers. The first row of Table 4 summarises the key patterns in Figure 2. Mean employment for the treatment group in the month prior to hiring a subsidised worker is 11.7. By construction, the treatment and comparison groups have the same prior employment level. The treatment group, however, uses subsidised workers more intensively even prior to the subsidy start that defines the reference month. On average, they employ 0.2 more subsidised employees than the firms in the matched comparison group. This necessarily implies that the treatment group has a lower level of unsubsidised employment prior to treatment.

In the reference month, the treatment group firms hire, on average, 1.09 subsidised workers, and have total employment that is 1.39 employees higher than in comparison firms. The fourth column of Table 4 shows that the additional expansion is largely due to the hiring of 0.48 other (non-subsidised) workers. The fact that the treated firms hire 1.57 more employees than the comparison group, but have employment that is only 1.39 higher, implies that the treatment group have a slightly higher rate of job separations. The substantial net increase in employment indicates, however, that firms taking on subsidised workers are not simply substituting subsidised workers for unsubsidised workers. There is a difference in employment between the matched treatment and comparison groups even 36 months after the reference month, which is evident in Figure 3 and in the final columns of Table 4. The effect of treatment on the treatment group is 0.82 additional employees 12 months after the subsidised hiring, and remains substantial even after 36 months, at 0.52 .

The lighter solid line in the lower panel of Figure 4 plots the difference between the treatment and comparison groups in their use of subsidised workers. The dashed line shows the treatment-comparison difference in the employment of workers who were previously employed

\footnotetext{
${ }^{5}$ Standard errors are calculated from 100 bootstrap replications over the population of firms, with block selection of each firm's entire history. Within each replication, an independent random sample is chosen for estimation of the propensity score.
}

with a subsidy. The implications of the fact that jobs last longer than the associated subsidy are clearly evident. In the months after the reference month, the number of subsidised workers declines, as subsidies come to an end. There is, however, an accompanying increase in the employment of workers remaining after the end of their subsidy. The employment of formerly subsidised workers accounts for about 70 percent of the treatment effect after 12 months, and about half of the treatment effect 36 months after the subsidy starts.

The pattern of estimated impacts is fairly consistent across different firm size classes. For small firms (average employment of 5 or less), the impact on total employment is smaller than the number of subsidised workers who are hired, despite the positive contribution of other hires. This implies that there is some substitution of subsidised workers for unsubsidised workers, possibly due to difficulties in making fine adjustments to employment when the number of employees is small. Substitution is not evident for firms with average employment of more than 5 .

Consistent with the recent studies by Rotger and Arendt (2010) and Kangasharju (2007), we find that firms hiring subsidised workers increase their total employment relative to a sample of otherwise similar firms when they take on subsidised workers. Subsidised workers are not merely claiming subsidies to fill jobs that were previously filled by unsubsidised workers.

We estimate that the employment of unsubsidised workers actually increases when subsidised workers are hired. Most small to medium firms (50 or fewer employees) hiring subsidised workers take on only one subsidised worker at a time. On average, the number of subsidised workers hired in a month in these 'treated' firms is 1.09. Compared with employment changes among a group of matched comparison firms, employment in treated firms increases by 1.39 in the subsidy-start month, and is accompanied by a comparatively large hiring of unsubsidised workers (0.48 higher).

There is some evidence of weak substitution for very small firms (5 or fewer employees). For firms with average employment of 2 or fewer in the previous year, subsidised hires in the month of hiring average 1.04, yet total employment increases by only 0.96 employees, despite hiring more unsubsidised workers than comparable firms. At least some of these very small firms decrease their employment of unsubsidised workers when they hire a subsidised worker.

Treated firms continue to have higher employment levels than matched comparison firms for at least 36 months after a subsidy hire, although the size of the difference declines over time. The retention of subsidised workers after the end of their subsidy contributes significantly to the employment effect. The expansion of employment does not appear to be due to firms paying lower wages. The differences in average monthly earnings between the 
treatment and comparison groups are small and generally insignificant.

It seems likely that subsidised workers are filling at least some of the vacancies that would have been filled anyway. We are unable to distinguish this from the possibility that subsidies are effective in inducing firms to expand employment beyond what they would have chosen otherwise, or to bring forward future employment growth by hiring a subsidised worker at the same time as they are actively hiring unsubsidised workers.

\section{Conclusions}

Overall we find that starting a subsidised job leads to significant employment and earning benefits for assisted jobseekers over several years, and that the positive impacts are evident for all subgroups defined by previous benefit receipt or by demographic characteristics such as age, gender, and ethnicity. Subsidised workers are disproportionately hired into expanding firms, though we cannot determine whether the expansion would have occurred in the absence of the subsidy.

\section{References}

Calmfors, L., Forslund, A., \& Hemström, M. (2001). Does active labour market policy work? Lessons from the Swedish experience. Swedish Economic Policy Review, 8, 61-124.

Crichton, S., \& Maré, D. C. (2012). The impacts of wage subsidies on jobseekers' outcomes and firm employment. Wellington: Ministry of Business, Innovation \& Employment.

de Boer, M. (2003). Estimating the impact of employment programmes on participants' outcomes. Wellington: CSRE, Ministry of Social Development.

Department of Labour. (1985). Studies of employment and training programmes. Wellington: NZ Department of Labour.

Fabling, R. (2011, 11-01). Keeping it together: Tracking firms in New Zealand's Longitudinal Business Database. Motu Working Paper 11-01.

Fabling, R., \& Maré, D. C. (2012). Cyclical labour market adjustment in New Zealand: The response of firms to the global financial crisis and its implications for workers. Motu Working Paper 1204.

Heckman, J., Lalonde, R., \& Smith, J. (1999). The economics and econometrics of active labour market programs. In O. a. Ashenfelter, Handbook of Labor Economics: Vol 3. Amsterdam: Elsevier Science.

Labour Employment and Work in New Zealand 2012
Johri, R., de Boer, M., Pusch, H., Ramasamy, S., \& Wong, K. (2004). Evidence to date on the working and effectiveness of ALMPs in New Zealand. Wellington: Department of Labour and Ministry of Social Development.

Kangasharju, A. (2007). Do wage subsidies increase employment in subsidized firms? Economica 74, 51-67.

Maré, D. C. (2002). The impact of employment policy interventions. Labour Market Bulletin 2000-2002, $57-100$

Maré, D. C. (2005). Indirect effects of active labour market policies. Motu Working Paper 05-01.

NZ Employment Service. (1994). Evaluating the effectiveness of Job Plus. Wellington: Operations and Policy, NZ Employment Service.

OECD. (1993). Chapter 2: Active labour market policies: Assessing macroeconomic and microeconomic effects. In Employment Outlook 1993 (pp. 39-80). Paris: OECD.

Rosenbaum, P., \& Rubin, D. (1983). The central role of the propensity score in observational studies for causal effects. Biometrika 70(1), 41-55.

Rotger, G. P., \& Arendt, J. N. (2010). The effect of a wage subsidy on employment of the subsdised firm. AKF Working Paper, 2010(14).

\section{Disclaimer}

This paper was undertaken while the authors were on secondment to Statistics New Zealand. The results in this paper are not official statistics, they have been created for research purposes from the Integrated Data Infrastructure (IDI) prototype managed by Statistics NZ. The opinions, findings, recommendations and conclusions expressed in this are those of the authors. Statistics NZ and the Ministry of Business, Innovation and Employment take no responsibility for any omissions or errors in the information contained here.

Access to the data used in this study was provided by Statistics NZ in accordance with security and confidentiality provisions of the Statistics Act 1975. Only people authorised by the Statistics Act 1975 are allowed to see data about a particular person, business or organisation. Careful consideration has been given to the privacy, security and confidentiality issues associated with using administrative data in the IDI prototype. Further detail can be found in the Privacy impact assessment for the Integrated Data Infrastructure available from www.stats.govt.nz. The results in this paper have been confidentialised to protect individual people and businesses from identification.

The results are based in part on tax data supplied by Inland Revenue to Statistics NZ under the Tax 
Administration Act 1994. This tax data must be used only for statistical purposes, and no individual information may be published or disclosed in any other form, or provided to Inland Revenue for administrative or regulatory purposes.

Any person who has had access to the unit-record data has certified that they have been shown, have read, and have understood section 81 of the Tax Administration Act 1994, which relates to secrecy. Any discussion of data limitations or weaknesses is in the context of using the IDI prototype for statistical purposes, and is not related to the data's ability to support Inland Revenue's core operational requirements 
Figure 1: Jobseeker analysis: Selected outcomes for participants and matched comparisons

a) Receiving benefit or wage subsidy

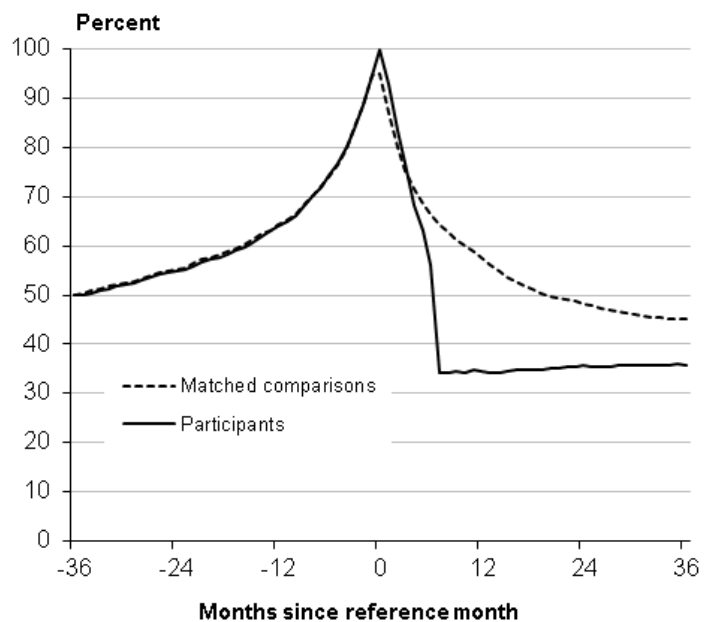

c) Employed

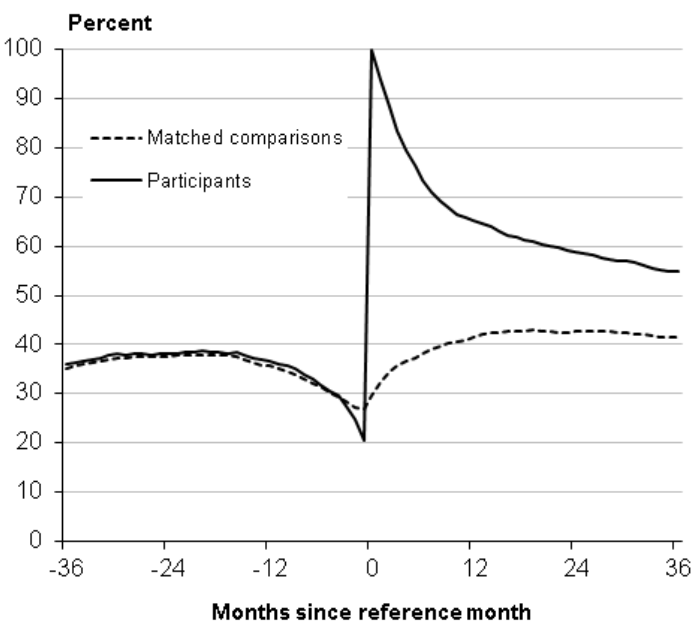

e) Neither employed nor receiving benefit

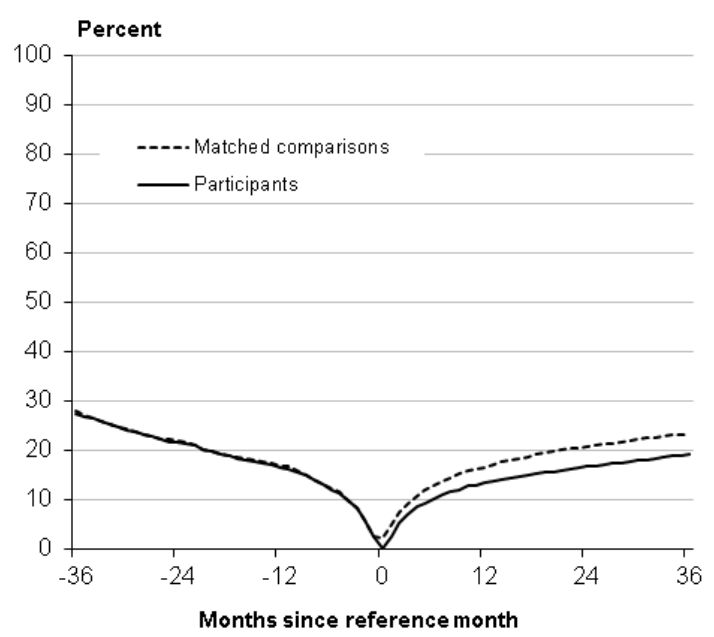

b) Unsubsidised employment and off-benefit

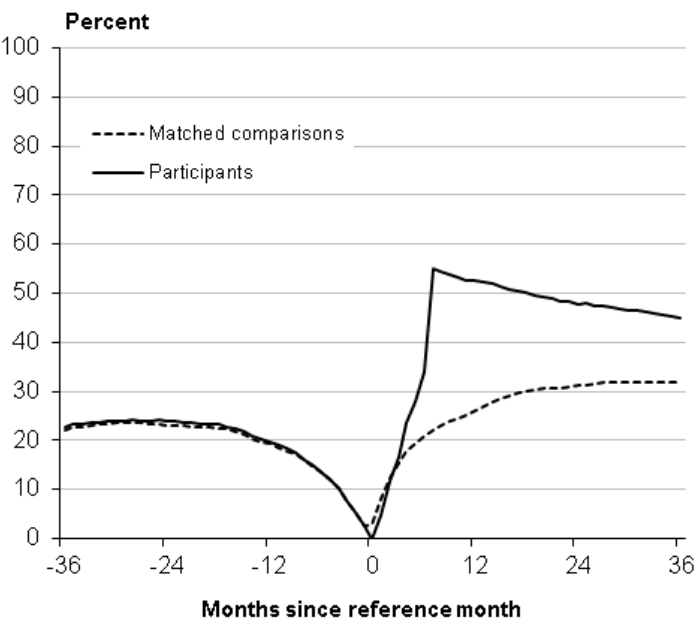

d) Employed and off-benefit

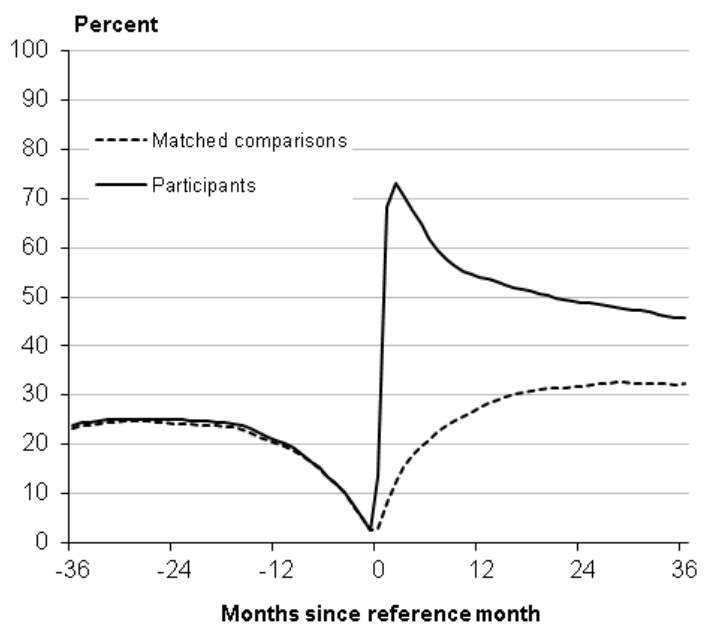

f) Subsidised employment

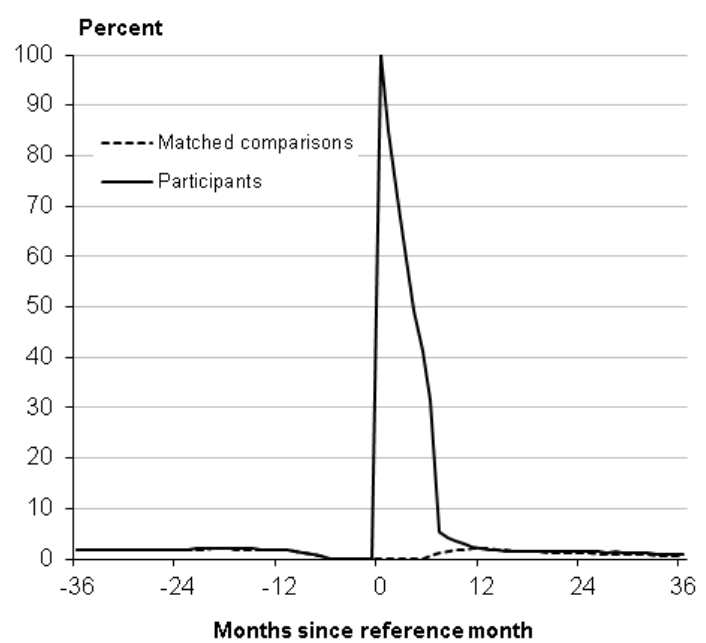


Figure 2: Firm analysis: Outcomes for treatment and comparison groups (for firms with mean annual employment 50 or less)
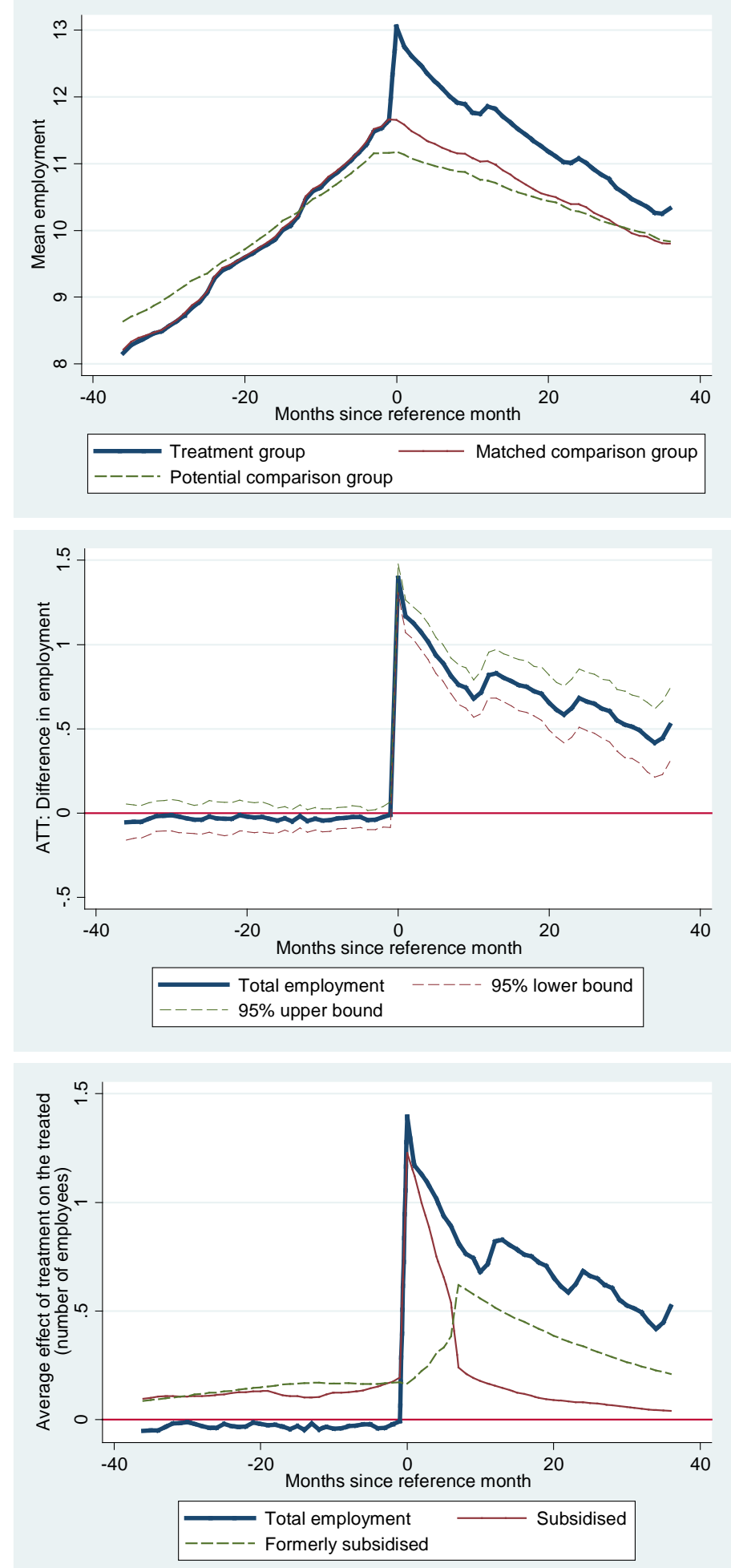

Note: Figures have been derived from the Integrated Data Infrastructure (IDI) prototype managed by Statistics New Zealand. Confidence intervals in the middle panel are calculated based on bootstrap standard errors (100 replications, sampled at the firm level prior to propensity estimation). 


\begin{tabular}{|l|l}
\hline & Non-participants \\
\hline
\end{tabular}

Number of observations

285,339

39,885

Demographic characteristics

Average age

Male

No school qualifcations

Tertiary qualifactions

Highest qualifaction not specified

Maori

Pacific

Partnered

Have dependant children

Migrant

Benefit type

Domestic Purposes

Independent Youth

Invalids

Sickness

Unemployment

Training

Program participation in the last three years

Training Incentive Allowance

Training Opportinities

Wage subsidy

Wage subsidy

Current benefit duration

Not on benefit in month started subsidised work

Less than 3 months

Ten years or more

Median current benefit duration (months)

Average number of months on benefit in the previous

12 months

Benefit history over the last 10 years

Median cumulative benefit duration (years)

Cummulative duration less than 12 months

Cummulative duration of $6-<10$ years

On benefit for the last 10 years

Employment and earnings history

Number of months on employed and off-benefit in the previous 12 months

Median monthly earnings (while employed and off-benefit) in the previous

24 months

Notes: All counts have been randomly rounded to base 3. Figures have been derived from the Integrated Data Infrastructure (IDI) prototype managed by Statistics New Zealand
38.3

$\begin{array}{rr}5.1 & 3.8 \\ 4.6 & 4.6 \\ 29.0 & 28.5 \\ 15.0 & 4.8\end{array}$


Table 2: Jobseeker analysis: Estimated impacts on participants three years after starting a subsidised job

\begin{tabular}{|c|c|c|c|c|c|c|c|c|}
\hline & $\mathbf{N}$ & $\begin{array}{c}\text { Receiving } \\
\text { benefit } \\
36 \text { months } \\
\text { later }\end{array}$ & $\begin{array}{c}\text { Employed } \\
36 \text { months } \\
\text { later }\end{array}$ & $\begin{array}{c}\text { Employed } \\
\text { and } \\
\text { off-benefit } \\
36 \text { months } \\
\text { later }\end{array}$ & \begin{tabular}{|c|} 
Number of \\
months \\
receiving \\
benefit over \\
the following \\
36 months
\end{tabular} & $\begin{array}{l}\text { Number of } \\
\text { months } \\
\text { employed } \\
\text { over the } \\
\text { following } \\
36 \text { months }\end{array}$ & $\begin{array}{l}\text { Number of } \\
\text { months } \\
\text { employed } \\
\text { and } \\
\text { off-benefit } \\
\text { over the } \\
\text { following } \\
36 \text { months } \\
\end{array}$ & $\begin{array}{l}\text { Average } \\
\text { total } \\
\text { earnings } \\
\text { over the } \\
\text { following } \\
36 \text { months }\end{array}$ \\
\hline Total & 38,808 & -10.2 & 12.8 & 13.0 & -5.0 & 4.8 & 6.1 & 20,150 \\
\hline \multicolumn{9}{|l|}{ Benefit Type } \\
\hline Domestic Purposes & 4,251 & -16.5 & 15.0 & 16.8 & -7.7 & 5.7 & 7.8 & 24,780 \\
\hline Invalids & 2,028 & -12.2 & 22.9 & 13.9 & -4.2 & 7.7 & 4.7 & 20,240 \\
\hline Independent Youth & 597 & ${ }^{\#}-5.7$ & ${ }^{\#} 5.4$ & ${ }^{\#} 5.2$ & -4.4 & 3.3 & 4.5 & 13,470 \\
\hline Sickness & 2,883 & -9.9 & 12.8 & 11.9 & -4.9 & 5.6 & 6.0 & 21,650 \\
\hline Training & 2,628 & -13.0 & 12.8 & 14.3 & -6.3 & 5.4 & 7.3 & 24,030 \\
\hline Unemployment & 26,334 & -8.8 & 11.8 & 12.4 & -4.5 & 4.3 & 5.8 & 18,950 \\
\hline \multicolumn{9}{|l|}{ Age } \\
\hline 16-17 years & 567 & ${ }^{\#}-6.8$ & ${ }^{\#} 5.4$ & ${ }^{\#} 6.6$ & -4.4 & 3.4 & 4.6 & 14,496 \\
\hline 18-19 years & 5,061 & -9.3 & 10.1 & 10.8 & -4.0 & 3.7 & 5.0 & 15,783 \\
\hline 20-24 years & 9,381 & -8.4 & 10.2 & 10.6 & -4.0 & 3.7 & 5.1 & 16,187 \\
\hline 25-34 years & 9,951 & -7.5 & 11.4 & 10.9 & -4.3 & 4.4 & 5.6 & 19,166 \\
\hline 35-44 years & 7,722 & -12.0 & 13.9 & 14.5 & -5.9 & 5.5 & 6.9 & 23,327 \\
\hline 45-54 years & 4,329 & -14.5 & 17.3 & 18.1 & -7.0 & 6.3 & 8.0 & 26,726 \\
\hline 55-64 years & 1,356 & -15.5 & 23.7 & 24.0 & -8.0 & 8.7 & 10.1 & 32,987 \\
\hline \multicolumn{9}{|l|}{ Sex } \\
\hline Male & 25,530 & -9.3 & 13.0 & 12.9 & -4.6 & 4.9 & 6.0 & 20,637 \\
\hline Female & 13,278 & -11.9 & 12.4 & 13.1 & -5.7 & 4.6 & 6.3 & 19,204 \\
\hline \multicolumn{9}{|l|}{ Ethnicity } \\
\hline Asian & 1,263 & -14.1 & 17.3 & 18.1 & -6.3 & 6.6 & 7.9 & 25,788 \\
\hline European & 17,754 & -9.9 & 13.8 & 13.8 & -4.8 & 4.9 & 6.2 & 20,651 \\
\hline Maori & 15,297 & -10.2 & 11.2 & 11.7 & -5.1 & 4.4 & 5.7 & 18,965 \\
\hline Pacific & 3,465 & -8.6 & 11.2 & 11.3 & -4.6 & 4.4 & 5.8 & 18,949 \\
\hline Other & 831 & -14.2 & 18.2 & 17.6 & -6.6 & 6.9 & 7.8 & 26,482 \\
\hline \multicolumn{9}{|l|}{ Current duration } \\
\hline$<6$ months & 13,092 & -4.6 & 9.0 & 9.1 & -2.0 & 2.6 & 3.9 & 13,469 \\
\hline $6-<24$ months & 13,497 & -10.5 & 11.5 & 12.6 & -5.6 & 4.8 & 6.6 & 21,502 \\
\hline $2-<4$ years & 4,554 & -13.7 & 14.7 & 15.7 & -7.3 & 6.7 & 8.0 & 26,011 \\
\hline 4 years + & 6,465 & -19.0 & 21.0 & 19.9 & -8.1 & 7.6 & 8.3 & 26,994 \\
\hline
\end{tabular}

Notes: All counts have been randomly rounded to base 3. Figures have been derived from the Integrated Data Infrastructure (IDI) prototype managed by Statistics New Zealand. Dollar figures are expressed in March 2009 dollars. The term 'employed' refers to unsubsidised employment. Average monthly earnings is conditional on having non-zero earnings in the month. Average total earnings includes months with no earnings and includes earnings from subsidised employment. All estimates are significant at the $5 \%$ level, unless indicated by a hash (\#). Statistical significance is calculated based on bootstrap standard errors (100 replications, sampled at the individual level prior to propensity estimation). 
Table 3: Firm analysis: Characteristics of treatment and comparison group (size $\leq 50$ employees)

\begin{tabular}{lrr}
\hline & $\begin{array}{r}\text { Potential } \\
\text { comparison }\end{array}$ & $\begin{array}{r}\text { Matched } \\
\text { treatment }\end{array}$ \\
\hline Number of enterprise-months & $7,974,626$ & 27,597 \\
Mean annual employment & 6.1 & 11.3 \\
Anrual employment growth (\%) & 8 & 13 \\
Annual hiring rate (\%) & 13 & 16 \\
Firn age $\geq 3$ years (\%) & 62 & 65 \\
Male (\%) & 54 & 61 \\
Young $(\%)$ & 22 & 29 \\
Low eamers $(\%)$ & 48 & 51 \\
Previous subsidy $(\%)$ & 5 & 44 \\
\hline
\end{tabular}

Notes: All counts have been randomly rounded to base 3. Figures have been derived from the Integrated Data Infrastructure (IDI) prototype managed by Statistics New Zealand.

Table 4: Firm analysis: Summary of average effects of treatment on the treated

\begin{tabular}{|c|c|c|c|c|c|c|c|}
\hline & \multicolumn{2}{|c|}{$\begin{array}{l}\text { In month prior to } \\
\text { subsidy start }\end{array}$} & \multicolumn{3}{|c|}{ In month of subsidy start } & \multirow{2}{*}{$\begin{array}{c}12 \\
\text { months } \\
\text { later } \\
\text { ATT } \\
\text { (total } \\
\text { empl.) } \\
\end{array}$} & \multirow{2}{*}{$\begin{array}{c}36 \\
\text { months } \\
\text { later } \\
\text { ATT } \\
\text { (total } \\
\text { empl.) } \\
\end{array}$} \\
\hline & $\begin{array}{l}\text { Mean total } \\
\text { empl. }\end{array}$ & $\begin{array}{l}\text { ATT } \\
\text { (Subs. } \\
\text { empl.) } \\
\end{array}$ & $\begin{array}{l}\text { Subsidy } \\
\text { starts }\end{array}$ & $\begin{array}{c}\text { ATT } \\
\text { (Other } \\
\text { hires) }\end{array}$ & $\begin{array}{c}\text { ATT } \\
\text { (total } \\
\text { empl.) }\end{array}$ & & \\
\hline All (emp $\leq 50)$ & 11.7 & 0.2 & 1.09 & 0.48 & 1.39 & 0.82 & 0.52 \\
\hline \multicolumn{8}{|c|}{ Employment size class } \\
\hline$(0,2]$ & 1.5 & 0.0 & 1.04 & 0.15 & 0.96 & 0.6 & 0.43 \\
\hline$(2,5]$ & 3.6 & 0.1 & 1.05 & 0.22 & 1.04 & 0.49 & 0.29 \\
\hline$(5,10]$ & 7.5 & 0.1 & 1.08 & 0.43 & 1.28 & 0.61 & ${ }^{\#} 0.22$ \\
\hline$(10,20]$ & 14.7 & 0.3 & 1.12 & 0.63 & 1.62 & 0.96 & 0.74 \\
\hline$(20,50]$ & 31.8 & 0.5 & 1.17 & 0.96 & 2.1 & 1.54 & ${ }^{\#} 1.05$ \\
\hline
\end{tabular}

Notes: All counts have been randomly rounded to base 3. Figures have been derived from the Integrated Data Infrastructure (IDI) prototype managed by Statistics New Zealand.. All estimates are significant at the 5\% level, unless indicated by a hash (\#). Statistical significance is calculated based on bootstrap standard errors (100 replications, sampled at the firm level prior to propensity estimation). 